\title{
CORRIGENDA
}

\section{DNA zip codes control an ancient mechanism for gene targeting to the nuclear periphery}

\section{Sara Ahmed, Donna G. Brickner, William H. Light, Ivelisse Cajigas, Michele McDonough, Alexander B. Froyshteter, Tom Volpe and Jason H. Brickner}

Nature Cell Biol. 12, 111-118 (2010); published online 24 January 2010; corrected after print, 27 January 2010

In the version of this Article initially published, Fig. 4d was incorrectly labelled -Inositol" and "+Inositol”. They should actually be labelled "no GRS" and "+GRS". The correct version of this figure is shown below. This error has been corrected in the HTML and PDF version of the article.
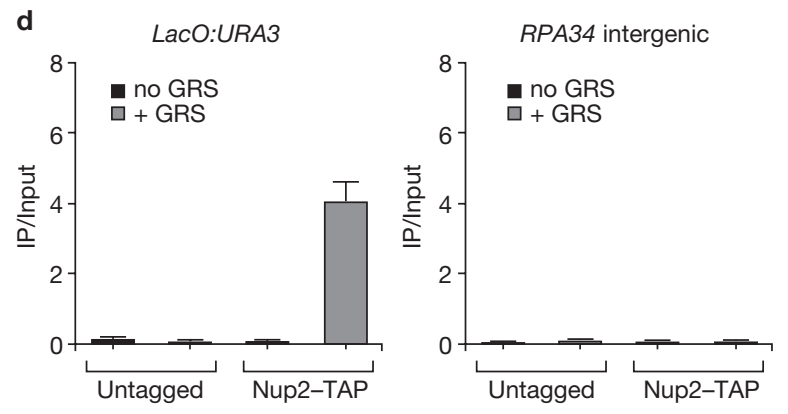

\section{Tipping the scale: muscle versus fat \\ Matthew S. Rodeheffer}

Nature Cell Biol. 12, 102-104 (2010); published online 17 January 2010; corrected after print, 21 January 2010

In the version of this News and Views initially published, cells are incorrectly referred to as " $\alpha 7$-integrin ${ }^{+}$. They should actually be " $a 7$-integrin-". This error has been corrected in the HTML and PDF version of the article. 